\title{
Eight Pack
}

National Cancer Institute

\section{Source}

National Cancer Institute. Eight Pack. NCI Thesaurus. Code C78780.

A product containing eight individual units. 